\title{
Hepatitis E vaccine
}

\author{
Rakesh Aggarwal $\cdot$ Shahid Jameel
}

Received: 12 December 2007 / Accepted: 15 February 2008/Published online: 10 April 2008

(C) Asian Pacific Association for the Study of the Liver 2008

\begin{abstract}
Hepatitis E is an emerging disease in resourcepoor regions of the world. It is estimated that about 2 billion people live in areas endemic for this disease. The inability to reproducibly culture hepatitis $\mathrm{E}$ virus makes it impossible to develop traditional live or inactivated vaccines. However, significant progress has been made in developing and testing recombinant subunit vaccines based on the viral capsid protein. This review summarizes these efforts.
\end{abstract}

Keywords Hepatitis · Hepatitis E · HEV · Vaccine

\section{Introduction}

Hepatitis, or inflammation of the liver, can be due to one of several causes including viruses, drugs, toxins, autoimmune diseases, etc. Among infectious agents, at least five viruses are known to primarily affect the liver and cause hepatitis-hepatitis A, B, C, and E viruses and the delta agent, abbreviated as HAV, HBV, HCV, HEV, and HDV, respectively. While infection with HAV and HEV causes only an acute, self-limited disease, the other agents are known to persist for long periods in some of those infected, leading to chronic hepatitis. It is estimated (R.H. Purcell,

\section{R. Aggarwal}

Department of Gastroenterology, Sanjay Gandhi Postgraduate Institute of Medical Sciences (SGPGIMS), Rae Bareilly Road, Lucknow 226 014, India

\section{S. Jameel $(\square)$}

Virology Group, International Centre for Genetic Engineering and Biotechnology (ICGEB), Aruna Asaf Ali Marg, New Delhi 110 067, India

e-mail: shahid@icgeb.res.in; jameelshahid@gmail.com personal communication (oral), July 2006) that of the 6 billion world population, the numbers of those who have been exposed to these viruses (and of those with chronic infection with each) are as follows: HAV, 5 billion (none); HBV, 4 billion (350 million); HCV, 200 million (170 million); HDV, 17 million (15 million), and HEV, 2 billion (none).

HEV causes hepatitis E, a disease transmitted predominantly through the fecal-oral route, primarily through contaminated drinking water [1]. Large waterborne outbreaks of hepatitis $\mathrm{E}$ have been recorded, besides rampant sporadic infections in endemic areas. Person-to-person transmission of HEV appears to be uncommon. The disease is clinically indistinguishable from hepatitis A. It generally has a low case mortality [1]; however, a peculiar feature of hepatitis $\mathrm{E}$ is its high mortality among pregnant women, reaching up to $20-30 \%$ [2].

The epidemiology of hepatitis $\mathrm{E}$ is more complex than was initially appreciated, and many features remain unexplained. The age-related seroprevalence of anti-HEV antibodies shows three different patterns. In endemic areas such as Asia, the Middle East, and North Africa, anti-HEV seroprevalence increases with age up to $30-40 \%$ in adults, whereas more than $95 \%$ of people older than 5 years living in these regions have anti-HAV antibodies [3]. Since both HEV and HAV are transmitted by the fecal-oral route and are endemic to the same regions, the reasons for this difference are not clear. However, the relatively low frequency of anti-HEV antibodies among adults possibly explains why hepatitis $\mathrm{E}$ is prevalent in young adults living in these regions. Another pattern has been observed in Egypt wherein anti-HEV is common in young children with seroprevalence rates reaching up to $70 \%$ by the third decade of life [4]. In these regions, hepatitis E epidemics are uncommon, though sporadic cases do occur. In 
developed countries of western Europe and the United States, hepatitis E is rare, and most cases are related to travel to HEV-endemic areas. However, surprisingly, relatively high rates of anti-HEV positivity were observed in US blood donors in comparison with those expected from the low disease rates. A possible explanation might be exposure to related animal viruses, for example, swine HEV, in these countries [5].

The HEV genome was first cloned and sequenced in the early 1990s from a Burmese isolate [6]. Subsequently, several isolates from other geographic regions have also been sequenced [7-11]. The HEV genome (Fig. 1) contains three open-reading frames (ORFs) that encode the ORF1 nonstructural polyprotein with proposed biochemical functions, the ORF2 major viral capsid protein, and the ORF3 regulatory protein [12]. Currently, HEV is classified into the family Hepeviridae and genus Hepevirus [13]. Based on the available nucleotide sequences, HEV isolates have been divided into five genotypes, each with a different geographical distribution. Of these, genotype 1 includes most human isolates from Asia and genotype 2 includes a solitary divergent human isolate from Mexico. Genotype 3 includes human and animal isolates from the United States, western Europe, Japan, Korea, Taiwan, Spain, and Argentina. Genotype 4 also includes human and animal isolates from China, Japan, Taiwan, and Vietnam, as well as swine (but not human) isolates from India. Genotype 5 includes the avian hepatitis E virus (AHEV), which has been described in chicken and turkeys, and shows about $50 \%$ nucleotide similarity to the human and swine HEV isolates. While the serotype status of AHEV is not fully understood, all human and mammalian HEV isolates belonging to genotypes 1-4 display a single serotype. This bodes well for the development of hepatitis E vaccines.

All hepatitis E vaccine efforts have so far focused on the ORF2 capsid protein of the virus (Fig. 1). Since the virus does not grow reliably to high titers in cell culture, traditional live attenuated or killed viral vaccine approaches have been ruled out. Various recombinant forms of the ORF2 protein, expressed using different heterologous systems, are being explored [14]. Recently, a few studies have also explored the use of ORF2-expressing naked DNA constructs. The details of these approaches are presented below.

\section{The immunologic basis for an HEV vaccine}

In spite of some contradictory observations, several lines of evidence suggest that recombinant subunit vaccines for hepatitis E might be feasible. Natural infections in humans, as also experimentally transmitted infections with HEV in the primate models, are associated with the development of serum antibodies to HEV [15]. Rechallenge with HEVcontaining inocula in animals with prior experimental HEV infection usually does not lead to reinfection, at least for a
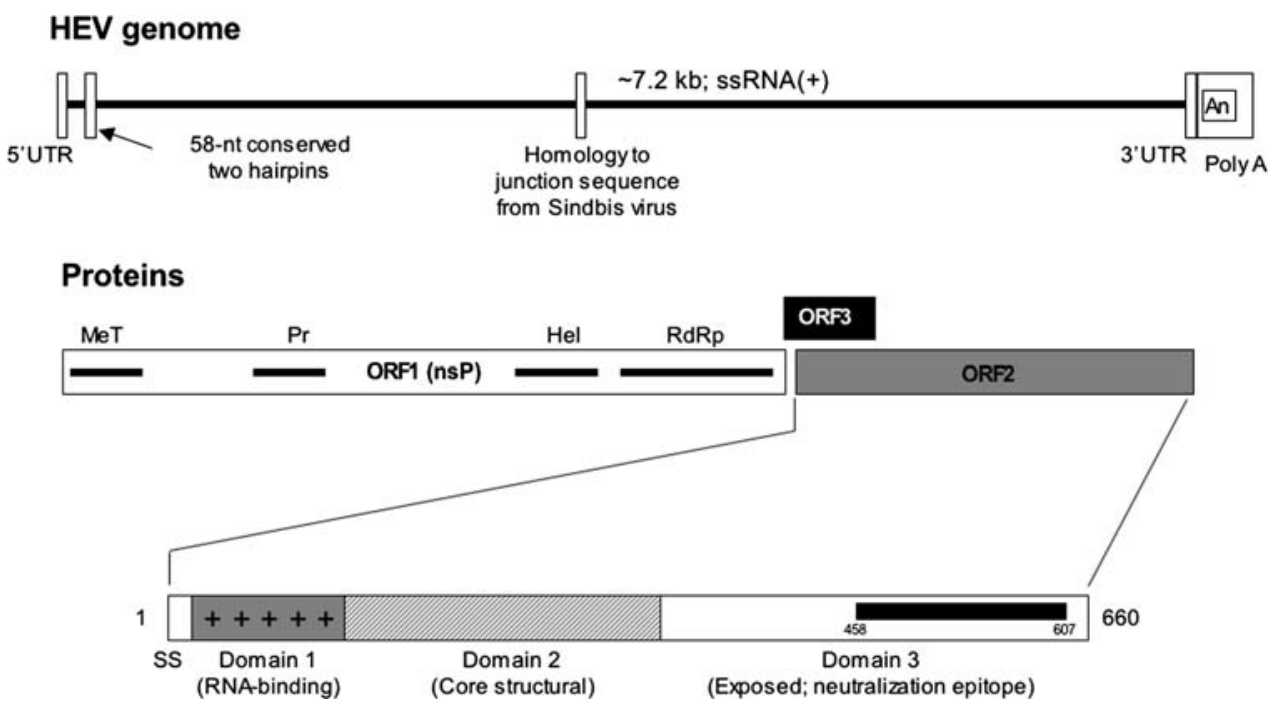

Fig. 1 The genome organization of HEV. The HEV genome is an $\sim 7.2$-kilobase $(\mathrm{kb})$ single-stranded $(+)$ sense RNA that encodes three open-reading frames: ORF1, ORF2, and ORF3. The ORF1 encodes the nonstructural polyprotein that contains various functional domains (methyltransferase, MeT; protease, Pr; RNA helicase, Hel; RNAdependent RNA polymerase, RdRp). The ORF2 encodes the viral capsid protein and ORF3, a protein with regulatory properties. The 660-amino acid ORF2 protein has an N-terminal signal sequence (SS) and three putative domains (S. Jameel, 2008). Of these, domain 1 ( $\sim 100$ residues) with a high density of arginine residues is likely to be involved in RNA encapsidation. Domain $2(\sim 240$ residues $)$ is predicted to form the core of the viral capsid and domain $3(\sim 300$ residues) is predicted to be exposed on the virus particle. A neutralization epitope (amino acids 458-607) was localized to domain 3 and is likely to be involved in the binding of HEV to its cellular receptor 
period of several months following the initial infection; however, anecdotal accounts of successful experimental infection of macaques in the presence of preexisting antiHEV antibodies are available. Epidemiologic observations during a hepatitis E outbreak suggest that people previously infected with HEV are protected during epidemics of the disease [16]. This is in agreement with the high attack rates observed among young adults. The duration of a protective antibody response following HEV infection, however, remains unresolved. While some studies have noted the disappearance of $\operatorname{IgG}$ anti-HEV within 612 months [17] or 1-4 years [17, 18], at least one study has reported the persistence of IgG anti-HEV for up to 14 years in about half of the people infected during an outbreak of hepatitis E [19]. It has been possible to protect macaques against experimental transmission of HEV by administering high-titer immune serum globulin [15]. However, pooled normal human immune plasma from an endemic area showed no protection in clinical trials, though this may have been related to the relatively low dose of the immunoglobulin used and the relatively low levels of antiHEV in the unselected pooled plasma [20, 21]. Similarly, anti-HEV-positive serum derived from a human volunteer with a history of hepatitis E 4 years ago did not protect macaques from experimental transmission of HEV [22]. Although at least four genotypes of HEV have been reported to exist globally [12, 23], these represent a single serotype of the virus $[23,24]$ and raise optimism that antibodies to one strain will protect against all others. Finally, antibodies to the ORF2 capsid protein of HEV were also found to neutralize the virus in vitro [25].

Together, these observations suggest that it may be possible to induce protective immunity against HEV infection by raising broadly reactive antibody responses to the ORF2 capsid protein. However, it appears that successful immunization will need to achieve higher and longer lasting antibody titers than those achievable in a natural infection.

\section{Recombinant protein vaccines}

Several recombinant ORF2 antigens of different lengths have been expressed using a variety of expression systems and have been shown to induce anti-ORF2 antibody responses (Table 1). While many truncated versions of the ORF2 protein have been expressed, purified, and tested for immunogenicity and efficacy, the size and nature of the
Table 1 HEV candidate vaccines

\begin{tabular}{|c|c|c|c|c|}
\hline HEV (source) & Name & $\begin{array}{l}\text { ORF2 amino } \\
\text { acids (range) }\end{array}$ & Reference & Remarks \\
\hline \multicolumn{5}{|c|}{ Proteins expressed in Escherichia coli } \\
\hline China & ORF2 & $1-660$ & {$[26]$} & Neutralizing $\mathrm{Ab}$ \\
\hline Burma & TrpE-C2 & $221-660$ & {$[27]$} & \\
\hline China & ORF2.1 & $394-660$ & {$[28]$} & \\
\hline China & $\mathrm{pE} 2$ & $394-604$ & [29] & Preclinical efficacy \\
\hline Mexico, Burma & 3.2 & $612-654$ & {$[30]$} & \\
\hline \multicolumn{5}{|c|}{ Proteins expressed in insect cells } \\
\hline Burma & $72 \mathrm{kDa}$ & $1-660$ & {$[31]$} & \\
\hline \multirow[t]{3}{*}{ Pakistan } & $63 \mathrm{kDa}$ & $112-660$ & {$[32]$} & \\
\hline & $56 \mathrm{kDa}$ & $112-607$ & {$[33]$} & $\begin{array}{l}\text { Preclinical efficacy; } \\
\quad \text { human clinical trials }\end{array}$ \\
\hline & $53 \mathrm{kDa}$ & $112-578$ & & VLPs; neutralizing $\mathrm{Ab}$ \\
\hline \multirow[t]{2}{*}{ Burma } & $62 \mathrm{kDa}$ & $112-636$ & {$[31]$} & Neutralizing $\mathrm{Ab}$ \\
\hline & $50 \mathrm{kDa}$ & $112-534$ & [34] & VLPs; preclinical efficacy \\
\hline \multicolumn{5}{|c|}{ Proteins expressed in other systems } \\
\hline \multirow[t]{2}{*}{ China } & $\mathrm{HBV} / \mathrm{HEV}$ & $551-607$ & {$[35]$} & In yeast Pichia pastoris \\
\hline & HEV-E2 & $394-604$ & {$[36]$} & In transgenic tomato \\
\hline \multicolumn{5}{|l|}{ Naked DNA } \\
\hline Burma & pJHEV & $1-660$ & [37] & \\
\hline India & pcDNA-ORF2 & $1-660$ & {$[38]$} & \\
\hline Burma & pcHEVORF2 & $1-660$ & [39] & Preclinical efficacy \\
\hline \multicolumn{5}{|l|}{ DNA plus protein } \\
\hline \multirow[t]{2}{*}{ India } & pcDNA-NE & $458-607$ & [40] & \\
\hline & $+26 \mathrm{kDa}$ & & {$[41]$} & Preclinical efficacy \\
\hline
\end{tabular}


native protein in $\mathrm{HEV}$ virions remains elusive. Five of these antigens (TrpE-C2, pE2, Pakistan $56 \mathrm{kDa}$, Burma $62 \mathrm{kDa}$, and Burma $50 \mathrm{kDa}$ ) have also been shown to produce neutralizing antibody responses (Table 1), and are therefore relevant to the discussion here as potential candidate vaccine antigens.

\section{Proteins expressed in Escherichia coli}

Only two of the proteins expressed in E. coli have shown promise as vaccine candidates, the rest being useful as diagnostic reagents. The first of these, TrpE-C2, contained a 221- to 660-amino acid carboxy-terminal fragment of the ORF2 protein of a Burmese strain (genotype 1) of $\mathrm{HEV}$ fused to tryptophan synthetase [27]. In preclinical challenge experiments, two cynomolgus macaques vaccinated with the recombinant TrpE-C2 protein were challenged with wild-type homologous (genotype 1) or heterologous (genotype 2) HEV. The animal receiving homologous challenge showed no evidence of HEV infection. However, the animal challenged with a heterologous Mexican strain of HEV did get infected as demonstrated by viremia, viral excretion, and increase in anti-HEV antibody levels, but did not develop biochemical or histological evidence of hepatitis.

Another candidate, pE2, was expressed as a glutathione$S$-transferase (GST) fusion protein containing amino acids 394-660 of the ORF2 protein from a Chinese isolate [29]. Following its purification and cleavage from the GST partner, the $\mathrm{pE} 2$ polypeptide was found to self-associate into a dimer. The dimeric form of the protein was efficiently recognized by convalescent human sera from patients with hepatitis E, and antibodies to it successfully recognized $\mathrm{HEV}$ in an immune capture assay [29]. Cynomolgus macaques vaccinated with $\mathrm{pE} 2$, but not control animals, showed efficient seroconversion and no infection following challenge with the homologous virus [42]. Another candidate vaccine expressed in bacteria, called HEV239, contains ORF2 amino acids 376-606 [43]. This consists of 23-nm particles that dissociate under mild denaturing conditions into homodimers [44] that react strongly with acute and convalescent sera of hepatitis E patients [43-45] and HEV-specific monoclonal antibodies [29]. In primate studies, this vaccine was found to give protection against HEV genotypes 1 and 4, and sera from vaccinated animals neutralized infectivity of $\mathrm{HEV}$ in vitro [43]. There are reports of human safety and efficacy trials of this vaccine, but no published results are yet available.

Proteins expressed in insect cells

The recombinant ORF2 proteins produced using baculovirus vectors in insect cells have been pursued vigorously as candidate vaccines. In this system, the $72-\mathrm{kDa}$ ORF2 protein of a Pakistani HEV strain (SAR55) is rapidly processed into smaller proteins of 63,56 , and $53 \mathrm{kDa}$. Of these, the $56-\mathrm{kDa}$ form accumulates in the cytoplasm of insect cells, whereas the $53-\mathrm{kDa}$ form is secreted as viruslike particles (VLPs) [32]. The recombinant 56-kDa ORF2 protein was found to be an efficient immunogen in monkeys when given with an alum adjuvant [15, 46]. Furthermore, the vaccinated animals were protected from intravenous challenges with high doses of both homologous and heterologous strains of $\operatorname{HEV~[15,46].~This~}$ candidate vaccine has moved further into preclinical development and human clinical trials [14].

A $62-\mathrm{kDa}$ recombinant ORF2 protein from a Burmese HEV strain produced in insect cells has also been tested in monkeys [47]. Two $20 \mu \mathrm{g}$ doses of an alum-adjuvanted preparation were shown to protect cynomolgus macaques against challenge by a heterologous HEV strain.

Similarly, insect cells expressing the ORF2 protein of the Burmese strain of HEV secreted VLPs made up of a 50-kDa protein [34]. Whether this protein and the 53-kDa secreted protein produced from insect cells expressing the SAR55 ORF2 protein are identical has not been determined. These VLPs, which are $24 \mathrm{~nm}$ in size, have been structurally characterized using cryoelectron microscopy [48] and have been found to induce both systemic and mucosal anti-HEV responses when administered orally to mice [49]. Cynomolgous macaques orally vaccinated with these VLPs, without any added adjuvant, have recently been shown to raise systemic and mucosal anti-HEV antibody responses [35]. Furthermore, these animals were fully protected against infection and hepatitis following an intravenous challenge with HEV [35]. These results raise the possibility of developing an oral recombinant hepatitis E vaccine. The HEV ORF2 VLPs have also been tested as an oral vaccine vehicle for presenting foreign epitopes [50] and to orally deliver encapsulated DNA to mucosal sites [51].

All the baculovirus-mediated ORF2 protein expression and purification have been carried out in either Sf21 or Tn5 insect cell lines. We have also explored the use of intact Spodoptera litura larvae for this purpose [52]. A recombinant baculovirus was engineered to express a truncated ORF2 antigen from an Indian strain of HEV. This contained amino acids 112-660 with an inframe deletion of a hydrophobic region between residues 585 and 610. High levels of the recombinant ORF2 antigen were expressed and found to accumulate in the larval fat bodies within 5 days of virus injection into fourth-instar $S$. litura larvae. The recombinant protein could be purified to homogeneity in an estimated yield of $0.2 \mathrm{mg}$ per larva [52]. This exemplified the use of insect larvae as bioreactors, a potentially economical method for recombinant protein expression. 
Proteins expressed in other systems

A C-terminal peptide of ORF2 encompassing amino acids 551-607 has been expressed on chimeric VLPs formed by the hepatitis B surface antigen ( $\mathrm{HBsAg}$ ) in the methylotropic yeast Pichia pastoris [53]. The VLPs showed reactivity to human sera containing antibodies against $\mathrm{HBV}$ as well as those with anti-HEV antibodies, and are being explored as a recombinant HBV/HEV bivalent vaccine candidate. In more recent studies, ORF2 antigens 69660 and 112-660 have been expressed independently in $P$. pastoris, and the purified proteins have been shown to induce high titer antibodies in rhesus monkeys [54].

The 23-kDa ORF2 antigen (pE2; residues 394-604), earlier expressed in bacteria [29], has recently been expressed in transgenic tomato plants [36]. The expression levels of the protein in this system were, however, quite low, being in the range of $40-60 \mathrm{ng} / \mathrm{g}$ of the leaf or fruit tissue [36].

\section{DNA vaccines}

Direct injection of plasmid DNA has been shown to cause intracellular synthesis of immunizing viral antigens, as well as induction of humoral and cellular immune responses. Vaccination with HEV ORF2 expression constructs has been shown to elicit anti-HEV antibodies [37, 38] and immunologic memory [55] in mice. These antibody responses can be augmented by codelivery of genes for the immunomodulatory cytokines interleukin 2 and granulocyte-macrophage colony stimulating factor [38]. In a preclinical efficacy experiment, cynomolgous macaques vaccinated with an ORF2 expression construct were protected from virus challenge only when the DNA was administered with a gene gun and not when it was given as an intradermal injection [39]. A DNA prime plus recombinant protein boost was recently shown to be immunogenic in mice [39]. This report utilized both DNA and recombinant protein representing the HEV ORF2 neutralizing epitope. An approach based on injection of a liposome carrying this DNA vaccine and a recombinant protein antigen was also reported to afford protection against virus challenge in rhesus macaques [41]. Although DNA vaccines have obvious advantages of stability and ease of preparation, much work remains on the mode of delivery and characterization of immune responses.

\section{Neutralization epitopes and assay systems}

Several ORF2 antigens have been shown to be immunogenic as well as to induce antibodies that recognize divergent strains of HEV. The important parameter for vaccine development is to ascertain whether these are capable of neutralizing both homologous and heterologous viral strains.

One neutralizing epitope has been identified between amino acids 578 and 607 of the ORF2 protein. It was observed that two neutralizing monoclonal antibodies selected by phage display binding to the ORF2 112-607 protein, but not to the ORF2 $112-578$ protein [56]. Antibodies to purified ORF2 proteins prepared in rabbits or guinea pigs are not as effective as antibodies found in convalescent human or macaque sera following infection, for in vitro neutralization of homologous or heterologous HEV strains. Shorter fragments of the ORF2 protein react more readily with antibodies in human sera than the fulllength protein $[34,57]$, suggesting that the neutralization (and immunodominant) epitopes may be masked in the longer proteins. These observations also emphasize that the tertiary structure of the protein used for vaccination is likely to be crucial.

An enzyme-linked immunosorbent assay (ELISA) for putative neutralizing antibodies to HEV has been developed that detects antibodies to all four genotypes of the virus [58]. This test has been used with sera from experimentally inoculated macaques, but remains to be evaluated in a human field situation. An ELISA based on truncated forms of the ORF2 protein has also been developed to differentiate between vaccination and infection (S. Emerson, personal communication (oral), May 2007). At this time, vaccination of cynomolgous or rhesus macaques, and their subsequent challenge with homologous and heterologous HEV strains, appears to be the best model for assaying the potential efficacy of a candidate vaccine. The in vitro assays for neutralizing antibodies against HEV and the full-length infectious clones of HEV [59, 60] may, in future, provide tools for quicker and easier assessment of protective efficacy of the induced antibodies.

\section{Clinical trials}

Preclinical immunogenicity and efficacy studies in humans have been conducted on only a limited number of HEV vaccine candidates. Of these, only 1 vaccine has so far progressed into human clinical trials. The 56-kDa baculovirus-expressed ORF2 protein developed at the National Institutes of Health, Bethesda, MD, was licensed to Glaxo SmithKline and was evaluated in humans by the Walter Reed Armed Forces Institute of Medical Sciences, Washington, DC [14]. Studies in rhesus macaques have shown this preparation to be highly immunogenic and efficacious in preventing infection following intravenous challenge with three different genotypes of HEV [61]. In phase I 
trials in healthy volunteers in the United States and Nepal, the vaccine proved to be safe and immunogenic [14, 62]. A 3 -dose immunization schedule with $1,5,20$, or $40 \mu \mathrm{g}$ of the recombinant protein gave progressively better titers with higher doses. With three doses of $40 \mu \mathrm{g}$ each, immunologic memory recall with geometric mean titers of about 75 WHO units/ml were attained [62].

Recently, the results of a phase II-III efficacy trial of this vaccine, which was carried out in Nepal, have been published [63]. The study included 2,000 volunteers from the Nepalese Army who tested negative for anti-HEV antibodies. They were randomized to receive $20 \mu \mathrm{g}$ of either the alum-adjuvanted recombinant HEV protein or a matched placebo, each given as three doses at 0,1 , and 6 months, and followed up for 2 years postvaccination. Overall, $88 \%$ of volunteers completed the study with median follow-up duration of 804 days. Among those who had received all three doses of the vaccine as scheduled, the rate of clinically overt (symptomatic) acute hepatitis $\mathrm{E}$ was markedly lower than those who received a matching placebo, with an impressive vaccine efficacy rate of $95 \%$. A somewhat lower efficacy rate of $85.7 \%$ was observed in the period between 14 days after dose 2 until dose 3 . Adverse effects of the vaccine were no different from those observed with the placebo, except for an increased injection-site pain. However, the study had some limitations. First, the study subjects were overwhelmingly (>99\%) men and were mostly young (mean age $=25$ years). Second, the authors did not study the HEV infection rate, focusing instead on clinical disease rate. And finally, by the end of the study, anti-HEV antibody titers had declined significantly so that nearly $44 \%$ of subjects had antibody titers below the level considered as protective.

\section{Conclusions}

Depending on the preclinical efficacy data and results of the clinical trial published only recently, the hepatitis $\mathrm{E}$ vaccine based on recombinant HEV ORF2 protein shows clear evidence of protection against occurrence of symptomatic hepatitis E. Although these results are very encouraging, several questions still remain to be answered. First, how long does the vaccine-mediated protection last? Can long-term immunity to hepatitis $\mathrm{E}$ be achieved through vaccination when it appears to wane off following natural infection? Second, it remains to be seen whether the vaccine offers protection only against symptomatic disease or also against $\mathrm{HEV}$ infection. In the former case, the vaccine would not be expected to make a major dent in the epidemiology of $\mathrm{HEV}$ infection in the endemic regions. However, several vaccines currently in use do not offer sterilizing immunity. In some clinical situations, protection from disease and the ensuing liver damage, especially the onset of fulminant hepatic failure, may be a desirable goal. In such situations, the vaccine may still be useful despite its failure to prevent the infection. Third, it is not clear whether the vaccine would be useful for postexposure prophylaxis. This is particularly important if the vaccine is to be used for controlling an HEV outbreak, wherein exposure to the infection has already occurred, possibly several days before the identification of the outbreak.

Who should get the vaccine? A vaccine, even one with short-term efficacy, is likely to benefit risk groups such as travelers to endemic areas and pregnant women living in endemic areas. Persons with underlying chronic liver disease are also at an increased risk of developing severe complications following HEV infection [64] and would be a large target group, especially in hepatitis $\mathrm{E}$ endemic regions. However, it will be important to test that the vaccine retains its efficacy in such groups.

While the development of an HEV vaccine is a welcome step, its dissemination remains an unexplored area. Experience in resource-poor countries, where hepatitis $\mathrm{E}$ is endemic, has shown that hepatitis $\mathrm{B}$ vaccine is not readily available to the population at risk even decades after its introduction. The vaccine cost, the cost of delivering it, and maintaining a cold chain will remain critical issues with the hepatitis E vaccine as with several others. Thus, while "proof of principle" for hepatitis E vaccination has been delivered, there are still several challenges that need to be overcome in future before the morbidity and mortality associated with HEV infection can be tackled successfully.

Acknowledgments The work in this study was supported by grants from the Department of Biotechnology (DBT) and Indian Council of Medical Research. The DBT also provided core infrastructure support to ICGEB.

\section{References}

1. Krawczynski K. Hepatitis E. Hepatology 1993;17:932-41.

2. Khuroo MS TM, Skidmore S, Sofi MA, Khuroo MI. Incidence and severity of viral hepatitis in pregnancy. Am J Med 1981; 70:252-5.

3. Arankalle VA, Tsarev SA, Chadha MS, Alling DW, Emerson SU, Banerjee K, et al. Age-specific prevalence of antibodies to hepatitis A and E viruses in Pune, India, 1982 and 1992. J Infect Dis 1995; 171:447-50.

4. Fix AD, Abdel-Hamid M, Purcell RH, Shehata MH, Abdel-Aziz F, Mikhail N, et al. Prevalence of antibodies to hepatitis E in two rural Egyptian communities. Am J Trop Med Hyg 2000;62: 519-23.

5. Thomas DL, Yarbough PO, Vlahov D, Tsarev SA, Nelson KE, Saah AJ, et al. Seroreactivity to hepatitis E virus in areas where the disease is not endemic. J Clin Microbiol 1997;35:1244-7.

6. Reyes GR, Purdy MA, Kim JP, Luk KC, Young LM, Fry KE, et al. Isolation of a cDNA from the virus responsible for enterically transmitted non-A, non-B hepatitis. Science 1990;247: 1335-9. 
7. Tam A, Smith MM, Guerra ME, Huang CC, Bradley DW, Fry $\mathrm{KE}$, et al. Hepatitis E virus (HEV): molecular cloning and sequencing of the full-length viral genome. Virology 1991;185: $120-31$.

8. Huang C, Nguyen D, Fernandez J, Yun KY, Fry KE, Bradley $\mathrm{DW}$, et al. Molecular cloning and sequencing of the Mexico isolate of hepatitis E virus (HEV). Virology 1992;191:550-8.

9. Tsarev SA, Emerson SU, Reyes GR, Tsareva TS, Legters LJ, Malik IA, et al. Characterization of a prototype strain of hepatitis E virus. Proc Natl Acad Sci U S A 1992;89:559-63.

10. Aye TT, Uchida T, Ma XZ, Iida F, Shikata T, Zhuang H, et al. Complete nucleotide sequence of a hepatitis $\mathrm{E}$ virus isolated from the Xinjiang epidemic (1986-1988) of China. Nucleic Acids Res 1992;20:3512.

11. Jameel S, Zafrullah M, Chawla YK, Dilawari JB. Reevaluation of a North India isolate of hepatitis E virus based on the full-length genomic sequence obtained following long RT-PCR. Virus Res 2002;86:53-8.

12. Jameel S. Molecular biology and pathogenesis of hepatitis E virus. Expert Rev Mol Med 1999;1999:1-16.

13. Virus Taxonomy 2002. http://www.ictvdb.rothamsted.ac.uk/ Ictv/fr-fst-g.htm.

14. Emerson SU, Purcell RH. Recombinant vaccines for hepatitis E. Trends Mol Med 2001;7:462-6.

15. Tsarev SA, Tsareva TS, Emerson SU, Govindarajan S, Shapiro M, Gerin JL, et al. Successful passive and active immunization of cynomolgus monkeys against hepatitis E. Proc Natl Acad Sci USA 1994;91:10198-202.

16. Bryan JP, Tsarev SA, Iqbal M, Ticehurst J, Emerson S, Ahmed A, et al. Epidemic hepatitis E in Pakistan: patterns of serologic response and evidence that antibody to hepatitis $\mathrm{E}$ virus protects against disease. J Infect Dis 1994;170:517-21.

17. Favorov MO, Fields HA, Purdy MA, Yashina TL, Aleksandrov AG, Alter MJ, et al. Serologic identification of hepatitis E virus infections in epidemic and endemic settings. J Med Virol 1992;36:246-50

18. Dawson GJ, Mushahwar IK, Chau KH, Gitnick GL. Detection of long-lasting antibody to hepatitis $\mathrm{E}$ virus in a US traveller to Pakistan. Lancet 1992;340:426-7.

19. Khuroo MS, Kamili S, Dar MY, Moecklii R, Jameel S. Hepatitis E and long-term antibody status. Lancet 1993;341:1355.

20. Joshi Y, Babu S, Sarin S, Tandon BN, Gandhi BM, Chaturvedi VC. Immunoprophylaxis of epidemic non-A non-B hepatitis. Indian J Med Res 1985;81:18-19.

21. Khuroo MS, Dar MY. Hepatitis E: evidence for person-to-person transmission and inability of low dose immune serum globulin from an Indian source to prevent it. Indian J Gastroenterol 1992;11:113-6.

22. Chauhan A, Dilawari JB, Sharma R, Mukesh M, Saroa SR. Role of long-persisting human hepatitis $\mathrm{E}$ virus antibodies in protection. Vaccine 1998;16:755-6.

23. Schlauder GG, Mushahwar IK. Genetic heterogeneity of hepatitis E virus. J Med Virol 2001;65:282-92.

24. Mast EE, Alter MJ, Holland PV, Purcell RH. Evaluation of assays for antibody to hepatitis E virus by a serum panel. Hepatitis E virus antibody serum panel evaluation group. Hepatology 1998;27:857-61.

25. Tam A, White R, Yarbough PO, Murphy BJ, McAtee CP, Lanford RE, et al. In vitro infection and replication of hepatitis $\mathrm{E}$ virus in primary cynomolgus macaque hepatocytes. Virology 1997;238:94-102.

26. Li F, Torresi J, Locarnini SA, Zhuang H, Zhu W, Guo X, et al. Amino-terminal epitopes are exposed when full-length open reading frame 2 of hepatitis E virus is expressed in Escherichia coli, but carboxy-terminal epitopes are masked. J Med Virol 1997;52:289-300.
27. Purdy MA, McCaustland KA, Krawczynski K, Spelbring J, Reyes GR, Bradley DW. Preliminary evidence that a trpE-HEV fusion protein protects cynomolgus macaques against challenge with wild-type hepatitis E virus (HEV). J Med Virol 1993;41:90-4.

28. Li F, Riddell MA, Seow HF, Takeda N, Miyamura T, Anderson DA. Recombinant subunit ORF2.1 antigen and induction of antibody against immunodominant epitopes in the hepatitis $\mathrm{E}$ virus capsid protein. J Med Virol 2000;60:379-86.

29. Zhang JZ, Ng MH, Xia NS, Lau SH, Che XY, Chau TN, et al. Conformational antigenic determinants generated by interactions between a bacterially expressed recombinant peptide of the hepatitis E virus structural protein. J Med Virol 2001;64:125-32.

30. Yarbough P, Tam AW, Fry KE, Krawczynski K, McCaustland KA, Bradley DW, et al. Hepatitis E virus: identification of typecommon epitopes. J Virol 1991;65:5790-97.

31. He J, Tam AW, Yarbough PO, Reyes GR, Carl M. Expression and diagnostic utility of hepatitis $\mathrm{E}$ virus putative structural proteins expressed in insect cells. J Clin Microbiol 1993;31: 2167-73.

32. Robinson RA, Burgess WH, Emerson SU, Leibowitz RS, Sosnovtseva SA, Tsarev S, et al. Structural characterization of recombinant hepatitis E virus ORF2 proteins in baculovirusinfected insect cells. Protein Expr Purif 1998;12:75-84.

33. McAtee CP, Zhang Y, Yarbough PO, Fuerst TR, Stone KL, Samander S, et al. Purification and characterization of a recombinant hepatitis $\mathrm{E}$ protein vaccine candidate by liquid chromatography-mass spectrometry. J Chromatogr B Biomed Appl 1996;685:91-104.

34. Li TC, Yamakawa Y, Suzuki K, Tatsumi M, Razak MA, Uchida T, et al. Expression and self-assembly of empty virus-like particles of hepatitis E virus. J Virol 1997;71:7207-13.

35. Li TC, Suzuki Y, Ami Y, Dhole TN, Miyamura T, Takeda N. Protection of cynomolgus monkeys against HEV infection by oral administration of recombinant hepatitis E virus-like particles. Vaccine 2004;22:370-7.

36. Ma Y, Lin SQ, Gao Y, Li M, Luo WX, Zhang J, et al. Expression of ORF2 partial gene of hepatitis E virus in tomatoes and immunoactivity of expression products. World J Gastroenterol 2003;9:2211-5.

37. He J, Binn LN, Caudill JD, Asher LV, Longer CF, Innis BL. Antiserum generated by DNA vaccine binds to hepatitis $\mathrm{E}$ virus (HEV) as determined by PCR and immune electron microscopy (IEM): application for HEV detection by affinity-capture RTPCR. Virus Res 1999;62:59-65.

38. Tuteja R, Li TC, Takeda N, Jameel S. Augmentation of immune responses to hepatitis E virus ORF2 DNA vaccination by codelivery of cytokine genes. Viral Immunol 2000;13:169-78.

39. Kamili S, Spelbring J, Carson D, Krawczynski K. Protective efficacy of hepatitis E virus DNA vaccine administered by gene gun in the cynomolgus macaque model of infection. J Infect Dis 2004;189:258-64.

40. Deshmukh TM, Lole KS, Tripathy, Arankalle VA. Immunogenicity of candidate hepatitis E virus DNA vaccine expressing complete and truncated ORF2 in mice. Vaccine 2007;25:4350-60.

41. Lipoxen Announces Positive Data for its ImuXen ${ }^{\circledR}$ Liposomal Technology. New Hepatitis-E Vaccine Candidate Poised to Enter Clinical Development http://www.lipoxen.co.uk/news/lipoxenannounces-positive-data-for-its-imuxen-liposomal-technology. aspx.

42. Im SW, Zhang JZ, Zhuang H, Che XY, Zhu WF, Xu GM, et al. A bacterially expressed peptide prevents experimental infection of primates by the hepatitis E virus. Vaccine 2001;19:3726-32.

43. Li SW, Zhang J, Li YM, Ou SH, Huang GY, He ZQ, et al. A bacterially expressed particulate hepatitis $\mathrm{E}$ vaccine: antigenicity, immunogenicity and protectivity on primates. Vaccine 2005;23:2893-901. 
44. Li SW, Zhang J, He ZQ, Gu Y, Liu RS, Lin J, et al. Mutational analysis of essential interactions involved in the assembly of hepatitis E virus capsid. J Biol Chem 2005;280:3400-6.

45. Zhang JZ, Ng MH, Xia NS, Lau SH, Che XY, Chau TN, et al. Conformational antigenic determinants generated by interactions between a bacterially expressed recombinant peptide of the hepatitis E virus structural protein. J Med Virol 2001;64: $125-32$.

46. Tsarev SA, Tsareva TS, Emerson SU, Govindarajan S, Shapiro M, Gerin JL, et al. Recombinant vaccine against hepatitis E: dose response and protection against heterologous challenge. Vaccine 1997;15:1834-8.

47. McAtee CP, Zhang Y, Yarbough PO, Bird T, Fuerst TR. Purification of a soluble hepatitis $\mathrm{E}$ open reading frame 2-derived protein with unique antigenic properties. Protein Expr Purif 1996;8:262-70.

48. Xing L, Kato K, Li T, Takeda N, Miyamura T, Hammar L, et al. Recombinant hepatitis E capsid protein self-assembles into a dual-domain $\mathrm{T}=1$ particle presenting native virus epitopes. Virology 1999;265:35-45.

49. Li T, Takeda N, Miyamura T. Oral administration of hepatitis E virus-like particles induces a systemic and mucosal immune response in mice. Vaccine 2001;19:3476-3484.

50. Niikura M, Takamura S, Kim G, Kawai S, Saijo M, Morikawa S, et al. Chimeric recombinant hepatitis $\mathrm{E}$ virus-like particles as an oral vaccine vehicle presenting foreign epitopes. Virology 2002;293:273-80.

51. Takamura S, Niikura M, Li TC, Takeda N, Kusagawa S, Takebe $\mathrm{Y}$, et al. DNA vaccine-encapsulated virus-like particles derived from an orally transmissible virus stimulate mucosal and systemic immune responses by oral administration. Gene Ther 2004;11: 628-35.

52. Sehgal D, Malik PS, Jameel S. Purification and diagnostic utility of a recombinant hepatitis E virus capsid protein expressed in insect larvae. Protein Expr Purif 2003;27:27-34.

53. Li H, Gang HY, Sun QM, Liu X, Ma YB, Sun MS, et al. Production in Pichia pastoris and characterization of genetic engineered chimeric HBV/HEV virus-like particles. Chin Med Sci J 2004;19:78-83.

54. Wang L, Zhuang H. Hepatitis E. an overview and recent advances in vaccine research. World J Gastroenterol 2004;10:2157-62.

55. He J, Hayes CG, Binn LN, Seriwatana J, Vaughn DW, Kuschner RA, et al. Hepatitis E virus DNA vaccine elicits immunologic memory in mice. J Biomed Sci 2001;8:223-6.

56. Schofield DJ, Glamann J, Emerson SU, Purcell RH. Identification by phage display and characterization of two neutralizing chimpanzee monoclonal antibodies to the hepatitis $\mathrm{E}$ virus capsid protein. J Virol 2000;74:5548-55.

57. Meng J, Pillot J, Dai X, Fields HA, Khudyakov YE. Neutralization of different geographic strains of the hepatitis $E$ virus with anti-hepatitis E virus-positive serum samples obtained from different sources. Virology 1998;249:316-24.

58. Zhou Y, Purcell RH, Emerson SU. An ELISA for putative neutralizing antibodies to hepatitis $\mathrm{E}$ virus detects antibodies to genotypes 1, 2, 3, and 4. Vaccine 2004;22:2578-85.

59. Panda SK, Ansari IH, Durgapal H, Agrawal S, Jameel S. The in vitro synthesized RNA from a cDNA clone of hepatitis $\mathrm{E}$ virus is indectious. J Virol 2000;74:2430-7.

60. Emerson SU, Zhang M, Meng X-J, Nguyen H, St Claire M, Govindarajan S, et al. Recombinant hepatitis E genomes infectious for primates: importance of capping and discovery of a cisreactive element. Proc Natl Acad Sci USA 2001;98:15270-5.

61. Purcell RH, Nguyen H, Shapiro M, Engle RE, Govindarajan S, Blackwelder WC, et al. Pre-clinical immunogenicity and efficacy trial of a recombinant hepatitis E vaccine. Vaccine 2003;21: 2607-15.

62. Safary A. Perspectives of vaccination against hepatitis E. Intervirology 2001;44:162-6.

63. Shrestha MP, Scott RM, Joshi DM, Mammen MP Jr, Thapa GB, Thapa N, et al. Safety and efficacy of a recombinant hepatitis E virus. New Engl J Med 2007;356:895-903.

64. Hamid SS, Atiq M, Shehzad F, Yasmeen A, Nissa T, Salam A, Siddiqui A, et al. Hepatitis E virus superinfection in patients with chronic liver disease. Hepatology 2002;36:474-8. 